\title{
ELECTRIC FENCING AGAINST GAME
}

\section{Experinients in TaNganyika}

"Unless revolutionary steps are taken to safeguard game, it will sooner or later be extinguished outside the reserves. It is imperative that game within the reserves be restricted for its own safety."

Thus writes Mr. G. H. Swynnerton in the Tanganyika Game Department's report for 1954. The trend is worldwide; of universal value therefore is knowledge of any economical means of kecping wild animals inside reserves or away from areas required by mankind. One such method is the electric fence, of which the great advantage is cheapness. An electric fence may cost only a fifth as much as a game-proof barbed-wire fence.

Two of the experiments are especially interesting :-

\section{EXPERIMEN'T B}

To study the effectiveness and economy of electric fencing in protecting native food crops against bushpigs, baboons, vervet monkeys, and bushbuck.

Locality.-Mnenya, Kondoa District.

Dates.-March to August, 1954.

Method:-One strand of mild steel galvanized wire (12 gauge) supported by plastic insulators nailed to wooden posts was mounted at a height of $\mathbf{1 5}$ inches round the outside of a plot roughly 100 acres in area. At the time of erecting the ferice (April and May) several crops growing on the plot were being caten and damaged by baboons, bushpigs, monkeys and bushbuck. These crops included maize, millet, groundnuts, sweet potato, sugar cane, cassava, oranges and guavas. The power unit for the fence was an ordinary electric fencer of the type used by farmers to fence cattle and was run from a six-volt car battery.

Up to the time the fence was erected the four animals named above had entered the plot frecly, causing damage.

Results : Bushpig.-The worst offenders were bushpig, of which at least one and usually more entered the plot every night destroying from ten to a hundred maize plants at a time, and digging up the root crops. After the fence had been erected, the pig damage ceased completely. Within the first week the evidence of pig spoor showed where pig had touched the wire and jumped back. Before running away they appeared to have rolled on the ground flattening several square yards of grass and 
undergrowth. It is of especial interest that damage was soon greatly reduced in the shambas outside the protected one.

Baboon.-It had been observed that the baboons which came regularly to raid the plot used their own few well-worn paths of approach. During the first week most of them jumped over the wire as it was only 15 inches high. At these approach points, two more wires were added at heights of 25 and 40 inches, and over distances of 100 yards. All the baboons received shocks trying to climb through the wires and within three weeks they had ceased to come to the shamba. It was apparent that the baboons were afraid to jump the single wire which surrounded the rest of the plot having received a shock from the trebled wire. The fence was removed early in August but the baboons were not seen again until the middle of October in the vicinity of this shamba.

Vervet Monkey.-The fence was not effective against vervet monkeys as they were able to run underneath it or to jump straight through where it was trebled.

Bushbuck.-For three weeks after the fence was erected bushbuck continued to come into the shamba by jumping over the 15-inch wire. However, their visits ceased after one month. It was evident from the spoor that bushbuck had touched the wire on many occasions and that where they had done so they had not jumped it. While the 15-inch wire is adequate against bushbuck where the wire is being used primarily against pig, a more effective height for bushbuck alone is 20 to 24 inches.

Conclusions from Experiment $B$.

It is concluded that electric fencing is effective against bushpig and bushbuck and against baboons when ereeted in the manner described above. It is not effective against monkeys.

The makers' instructions must be followed carefully and additional precautions which apply to the special conditions under which the fence is being used should be taken. These are :-

(1) The wire should not be placed where baboons can use a tree to climb or jump over it.

(2) Where pig are to be excluded some care is necessary to ensure that the wire is placed at or near to 15 inches above the ground. Unavoidable dips in the ground should be filled in or blocked with thorn scrub. It is essential to clear all folinge away from under the wire. 
(3) Under the relatively dry conditions often found in Tanganyika, it has been found advantageous to sink the earth pin of the fencer to a depth of 3 feet in damp soil. Thus, the machine is best placed where the earth pin can be sunk near a furrow, stream or pond.

The apparatus paid for itself at least twice over during the single crop season in which it was in use. One machine will electrify 10 miles of wire under dry conditions and 20 miles under damp conditions. Thus in large fencing projects the cost of the fencer and its battery are a small proportion of the total cost. The battery can be recharged in a motor vehicle.

\section{EXPERIMENT C}

To study the reactions of various game animals to an electrified wire fence.

Locality.-Two miles south of Maji Moto, west side of Lake Manyara.

Dates.-August to October, 1954.

Method.-A single strand of mild steel galvanized wire (12 gauge) mounted on plastic insulators nailed to wooden posts at a height of 40 inches was run from the rift escarpment in a straight line, out on to the semi-dry surface of Lake Manyara, a distance of about $1 \frac{1}{2}$ miles. At the escarpment end the fence was carried some way up the lower slopes to the base of a small cliff. At the lake end the wire was taken out on to the mud to a point where the softness made it inadvisable to go any further.

The wire was intended to be a barrier to the movement of large animals along the west side of the lake. For four-fifths of its length it ran over open level ground and for the other one-fifth it ran through light bush on the rising ground at the base of the scarp.

By sweeping the ground beside the wire every day it was found possible to makc a rough estimate of the number of sets of spoor of the animals that came to the wire during the night and to follow their actions.

The following animals came into contact with the wire:-

Elcphant, rhino, buffalo, giraffe, zcbra and wildebeest.

Elephant.-On most nights small herds of elephant (of about five to twenty per herd) came to the wire either from the north or from the south. During the first two wecks the wire was broken at at least one point on six different occasions by elephant. However, during the third week it was broken only once and once again during the fourth. After this the wire was not broken 
again. Their footprints showed clearly how they had touched the wire and turned away. On the nights that the elephant had touched the wire loud bellowings were heard and on one moonlit night their reactions were seen indistinctly. A herd of five was seen to approach the wire at a slow walk. They stopped at the wire and the leader, who seemed to be a cow, appeared to stand for about ten seconds nearly touching the wire. Suddenly she bellowed and turning round walked from the wire very briskly; the others followed.

Rlino.-There were seventeen visits by rhino to the fence of which all but two were made by single animals. Only four brealss-through occurred and three of these were in the first week and one was in the third. On arriving at the wire the most common behaviour seemed to have been to touch it once and then to walk along it touching it or nearly touching it at intervals of about fifty yards. After several unsuccessful attempts to get through the rhino would return in the direction from which he had come. On every occasion rhino approached the wire walking.

Buffalo.-A herd of at least fifty buffalo lived in a patch of forest about half a mile from the fence. Once during the first week and once during the third week the whole herd walked through the fence. The spoor was too confused to attempt to discover what had happened. On fourteen occasions single animals or small groups of five or less came to the wire. On six of these occasions the fence was broken and on the others the buffalo turned back after touching the wire. The breakages occurred during the first, third, fourth and sixth weeks. There was no evidence that any of the individual animals learned to avoid the wire. As there were so many buffalo in the area it is unlikely that more than a very small proportion touched the live wire.

One incident deserves mention. Buffalo spoor showed where a calf had walked under the wire while its mother remained on the other side. The mother touched the wire and did not follow. The calf returned and both went off together in the direction from which they had come.

The results as regards buffalo are inconclusive but they indicate that further experiments would be worthwhile. It seems probable that buffalo would learn to avoid the wire as several of them turned back on touching it the first time.

Giraffe.-Giraffe came to the wire on nine occasions and broke it four times. Unfortunately the wire only reached to the knees of an adult giraffe. It is unlikely that any individual touched 
the wire twice. 'The fact that they turned back on five occasions while receiving the shock in the leg indicates that better results would be obtained with the wire at neck height.

Zebra.-Two small herds of zebra, one of six individuals and the other of nine, came to the fence with the apparent intention of passing. Five of the first herd were seen to touch the wire and shy backwards at their first visit. 'Two days later they tried to pass again but they turned back without getting closer than ten yards from the fence. They did not return.

The second herd tried to pass and six were seen to walk up to the wire one at a time and to touch it. They also shied back and the herd returned. The same herd tried to pass on the following two days but stopped ten yards short of the wire before turning back.

It remains to be seen what would happen if a large herd tried to pass. It appears that small numbers at least can be restricted by electrified wire and there is every reason to suppose that unless a stampede occurred through the fence any number might be stopped.

Wildebeest. - The fence was placed through the middle of the grazing territory of a herd of about sixty wildebeest. When the posts for the fence had been put up, but not the wire, the herd congregated at a distance of 30 yards from it and charged through at a full gallop. When the wire was in place and electrified they repeated the performance, breaking the wire. This happened every day for ten days. In the second week they became accustomed to the sight of the fence and many of them walked up to it slowly. By the third week most of the herd had received a shock with the result that they avoided the fence and found their way round the end of it by struggling through mud in the lake. In preferring to wade through very sticky deep mud rather than touch the wire, which they could pass under by stooping or break by charging, the wildebeest showed a distrust for the fence which was quite unmistakable, but cannot be regarded as entirely conclusive for the purpose of the experiment.

\section{Conclusions from Experiment $C$.}

Several factors which could not be controlled tended to distort the experiment and to mask the results. Not the least of these was the relatively large number of animals coming into contact with the wirc. It is most unlikely that an electric fence would need to be placed where so many animals would touch it. For instance, it would be unusual for a herd of fifty buffalo to leave 
their normal habitat to walk across a farmer's land. Similarly, it is most unlikely that a fence would be placed across a normal migration route or in a position where it would prevent animals reaching their normal feeding or watering places. It will be appreciated that the fence used in the experiment was subjected to a very high " pressure" of game animals.

Another factor to be considered is that the apparatus used was not designed specially for the purpose but was intended for a less exacting task. There is no doubt that a more suitable apparatus could be made for a little extra expense.

When electric fencing is used to enclose domestic animals, it is usual to subject cach individual to an "educational" contact with the wire. This is often done by driving the animals into a small paddock one side of which consists of the electrified wire. When every animal has touched the wire the herd is sufficiently " educated" to avoid it in future.

There is the obvious difficulty when using the electric fence against game that their education will be much more uncontrolled. Every animal must get one shock before it learns to avoid the wire. What the animal does when it gets the shock is largely a matter of luck and differs from one species to another. It may jump back and run away, or it may jump forwards and break the wire if it is large. Fortunately it is much more usual for game animals to jump backwards than forwards when they get a shock. If the wire is broken other animals in the herd may walk through the gap. It will be appreciated that some patience is needed on the part of the owner of the fence because he will have to wait for one, two or even three weeks before all the animals that normally visit the fence have received a shock and are "educated". If this fact is not understood, the owner of the fence may decide that his fence is not working and will give up using it before the necessary education process has taken place.

Taking these factors into account the experiment shows that electric. fencing is a possible method of restricting the movement of game.

Nolc.-The 105.t Report of the Game Department, Tangnnyikn, may be bought for 3s. Bd. from 'The Government Printer, Dar-es-Salanm. It contains information about other experiments on electric fencing and nnimnl-proof hedges and also notes on the fauna of Tangnnyikn.-ED. 